\title{
Availability of sulphur amino acids in protein foods
}

\author{
3.* Chemical and nutritional changes in heated cod muscle \\ By E. L. MILLER, K. J. CARPENTER ANd C. K. MILNER \\ School of Agriculture, University of Cambridge
}

(Received 26 April I965-Accepted 22 fuly 1965)

In the first paper of this series (Miller \& Carpenter, 1964) it was reported that analysis of commercial animal protein concentrates for 'cystine + methionine' had given values which showed little correlation with the value of the materials in the rat net protein utilization (NPU) test even though the sulphur amino acid content was the limiting factor. Similarly Morrison \& Sabry $(1963)$ have noted some samples of fish flours in which the nutritive values, measured under conditions of methionine deficiency, were not related to the methionine content. Again, Ford (1962) has shown that in a series of whale-meat meals of widely differing protein quality there was little difference in the levels of several essential amino acids including methionine. Using the proteolytic organism Streptococcus zymogenes, Ford (1962) obtained 'available' methionine values for thirty-nine samples of animal protein concentrates which in all but six instances were less than two-thirds of the corresponding total values, and these lower 'available' values showed a closer correlation with rat NPU values.

In our second paper (Miller, Carpenter, Morgan \& Boyne, 1965) we confirmed, by direct determination of available methionine by a growth assay procedure with chicks, that a large proportion of methionine of animal protein concentrates can be present in an unavailable form. By comparison with these chick assay values the original procedure of Ford (1962) underestimated the available methionine content, but by increasing the concentration of papain used in the enzymic predigestion of the samples we obtained results in close agreement with the chick values. Subsequently Ford (1964) has confirmed the effect of higher papain concentration and also that other enzymes either singly or in combination do not bring about any further increase in available methionine value.

One explanation for the incomplete availability of methionine in some animal protein concentrates could be the indigestible nature of some of the raw materials used in their manufacture. On the other hand, it has been shown that excessive heating results in a decrease in fluorodinitrobenzene (FDNB)-available lysine (Carpenter, Ellinger, Munro \& Rolfe, 1957; Lea, Parr \& Carpenter, 1960; Carpenter, Morgan, Lea \& Parr, 1962), and it has been considered that the low FDNB-available lysine values found for some commercial meals must reflect heat damage. There is a considerable amount of indirect evidence that excessive heat also decreases the level of available sulphur amino acids. Thus Miller (1956) showed a decrease in NPU for rats

\footnotetext{
* Paper no. 2: Br. J. Nutr. (1965), 19, 249.
} 
on heating fish protein. Donoso, Lewis, Miller \& Payne (1962) have made a similar observation on heating pork protein. Under the conditions of the NPU test with these materials the sulphur amino acid content usually is the limiting factor. Also the data of many investigators, reviewed by Rice \& Beuk (1953), show that excessive heat results in a decreased in vitro enzymic release of methionine and other amino acids. So far as we know, the only direct evidence of the effect of heat upon the content of available methionine as determined by a biological assay is the report by Ousterhout, Grau \& Lundholm (1959) of a laboratory preparation of tunny-fish meal dried by heating for $3 \mathrm{~h}$ at $202^{\circ}$ in which the availability of methionine and methionine plus cystine were judged from a growth assay procedure with chicks to be $4^{\mathrm{I}}$ and $33 \%$ respectively. They further noted that the material was greatly charred and the damage was greater than would be met with in commercial materials. As a result of evaporation the temperature and moisture content of the preparation must have been changing during the course of heating.

In this paper we report experiments designed to study $(a)$ the extent to which methionine in cod muscle becomes unavailable as the result of heat treatment under a variety of controlled conditions, $(b)$ the changes in availability of methionine compared with changes in that of lysine and some other amino acids, and $(c)$, by comparison with values previously obtained for herring presscake meal (Carpenter et al. 1962), whether the heat-induced changes in amino acid availability are similar with different starting materials.

\section{EXPERIMENTAL}

\section{Preparation of the materials}

Freeze-dried cod muscle. This was cod muscle, i.e. fillets, that had been preheated in a commercial steam cabinet at $99^{\circ}$ for $4.5 \mathrm{~min}$, pressed to remove aqueous liquors, freeze-dried by an accelerated process and packed in cans under $\mathrm{N}_{2}$. In the laboratory, the resulting cod flake was hammer-milled to a coarse powder, gas-packed in 'oxygenfree' $\mathrm{N}_{2}$ and held at $-10^{\circ}$. (It was thus similar to the material used by Carpenter $e t a l$. (1957) except for the initial steaming and pressing.)

One portion was reground to pass a 60-mesh sieve, then used for preliminary experiments in which small samples were heated in sealed glass ampoules. In the light of these results, certain heat treatments were selected and applied to the coarsely ground starting material in sealed cans in sufficient quantity for the main experiments, including animal feeding trials.

Addition of glucose. When required a solution of D-glucose was added to cod-muscle powder in the proportion of either 5 parts glucose to 95 parts cod dry-matter or in the proportion of to to 90 parts respectively to form a slurry. After thorough mixing, the slurry was freeze-dried and reground.

Adjustment of moisture content. A portion of the finely ground cod muscle was further dried by heating at greatly reduced pressure over $\mathrm{P}_{2} \mathrm{O}_{5}$ for $24 \mathrm{~h}$ at $37^{\circ}$ and then for $\mathrm{I} 8 \mathrm{~h}$ at $70^{\circ}$. This material was used for studies of heating for $27 \mathrm{~h}$ at $I I 5^{\circ}$ and for $729 \mathrm{~h}$ at $85^{\circ}$. A second portion was dried, along with a sample of 'cod + glucose' powder by standing over $\mathrm{P}_{2} \mathrm{O}_{5}$ in an evacuated desiccator at room temperature for 
2 I days. These two materials were used to study the effect of temperatures up to $85^{\circ}$. Subsequent packing and sealing of these near-anhydrous materials into ampoules was as rapid as possible but slight uptake of moisture by the material may have taken place during these manipulations.

Samples were adjusted to approximately $14 \%$ moisture either by standing over sulphuric acid of sp.gr. 1.252 in an evacuated desiccator at room temperature for 4 days or, in the large-scale preparations, by spraying the required amount of water into constantly tumbled material. Further samples were similarly adjusted by spraying with water to $50 \%$ moisture. All materials in which water had been added as a spray were subsequently allowed to equilibrate for $24 \mathrm{~h}$ at $0^{\circ}$.

\section{Table I. Percentage moisture content of various cod-muscle preparations before heat treatment}

\begin{tabular}{|c|c|c|c|c|}
\hline \multirow{2}{*}{$\begin{array}{l}\text { Desired } \\
\text { content }\end{array}$} & \multicolumn{2}{|c|}{ Ampouled material } & \multicolumn{2}{|c|}{ Canned material* } \\
\hline & No glucose & Plus glucose & No glucose & Plus glucose \\
\hline of & $I \cdot 3$ & - & 一 & - \\
\hline 0 & $3 \cdot 1$ & $3 \cdot 1$ & - & - \\
\hline 14 & I3:3 & $14 \cdot 6$ & $\begin{array}{l}\text { I } 4.1\left(\mathrm{C}_{24}, \mathrm{C}_{26}\right) \\
\mathrm{I}_{3} \cdot 8\left(\mathrm{C}_{35}\right)\end{array}$ & 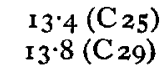 \\
\hline 50 & $48 \cdot 0$ & $52 \cdot 4$ & $48 \cdot 2\left(\mathrm{C}_{27}, \mathrm{C}_{28}\right)$ & - \\
\hline
\end{tabular}

* The code numbers in parentheses refer to the heated products which were prepared from these batches of material.

$\uparrow$ As explained (see p. 548), this sample was dried for $24 \mathrm{~h}$ at $37^{\circ}$ and then for $18 \mathrm{~h}$ at $70^{\circ}$, and then used only for the more severe heat treatments. The other ' $0 \%$ ' sample was dried in a desiccator at room temperature for 21 days.

The moisture contents of these control ampoules and of material prepared for canning are shown in Table $\mathrm{I}$. For ease of reporting, the moistures are referred to as $\circ, I_{4}$ or $50 \%$, but the figures as determined were used in all calculations.

Heat treatment of moisture-adjusted materials. To avoid loss of moisture during heat treatment, the materials were sealed into containers with minimum of head space. For the preliminary experiments, the samples were sealed under an atmosphere of 'oxygen-free' $\mathrm{N}_{2}$ in glass ampoules, as described by Carpenter et al. (1962). These were heated in thermostatically controlled ovens at temperatures up to $115^{\circ}$ for periods of from 9 to $729 \mathrm{~h}$. The coding used for these samples is not given as the results are presented in diagrams only.

For the main experiments cans $2 \frac{3}{4}$ in. high and 4 in. in diameter were completely filled and sealed under $\mathrm{N}_{2}$. The heat treatments used and the coding of the products (see Table 2) were as follows. An air oven was used for holding the cans at $55^{\circ}$ and $85^{\circ}$, but for higher temperatures autoclaving was used to prevent distortion of the cans by the internal pressures generated. Autoclaving was designed to produce a temperature of 1 I $5^{\circ}$ in the preparation of materials $\mathrm{C} 26$ and $\mathrm{C} 28$ but, as a result of inaccuracies in the pressure-gauge and mechanical failure of the gas regulating device, this was not attained. The actual temperature attained was estimated to be 100-105. A further sample, $\mathrm{C}_{35}$, was prepared and the temperature attained was determined as $116^{\circ}$ from a thermocouple in the autoclave. 
A thermometer placed in the ovens with the glass ampoules approached the required temperature after $20 \mathrm{~min}$. To allow for this delay the time that the ampoules were kept in the ovens was 20 min plus the designated time. Similarly there was a $2 \mathrm{~h}$ delay before the temperature recorded by a thermocouple inserted in the centre of a can of cod powder approached the external temperature and the cans were heated for $2 \mathrm{~h}$ more than the designated time.

Preparation of heated materials for analysis. The material in the several ampoules or cans heated under each condition was combined and remixed. Material at $50 \%$ moisture was redried by heating under greatly reduced pressure (oil pump) for $30 \mathrm{~h}$ at $37^{\circ}, \mathrm{P}_{2} \mathrm{O}_{5}$ being placed in the oven for the final $\mathrm{i} 2 \mathrm{~h}$. The coarsely ground material was used in all feeding trials, but all chemical and microbiological analyses were performed on samples reground to pass 60 mesh.

\section{Analytical procedures}

Water content. The moisture contents of the samples were determined by the procedure described by Carpenter et al. ( 1962 ).

Nitrogen content. Nitrogen was determined by the Kjeldahl method using a macrodigestion procedure (Association of Official Agricultural Chemists, I 960 ) followed by semi-micro distillation of the ammonia produced into $1 \%$ boric acid containing a mixed indicator and titration with $0.014 \mathrm{~N}-\mathrm{HCl}$ (Ma \& Zuazaga, 1942).

Assessment of colour. The colour of the samples was determined, using a spectrophotometer with reflectance attachment, by comparing the extinction at $500 \mathrm{~nm}$ with that of a standard white magnesium carbonate as previously reported by Carpenter et al. (1962).

Determination of $p H$. Samples of $0.5 \mathrm{~g}$ were mixed with $20 \mathrm{ml}$ distilled water and stood, with occasional stirring, for $\mathrm{I} h$ before the $\mathrm{pH}$ of the suspension was determined with a glass electrode.

'Total' amino acids. Methionine was determined by the three independent methods previously described (Miller \& Carpenter, 1964; Miller, Carpenter et al. 1965):

(I) Performic oxidation followed by acid hydrolysis and column chromatography of methionine sulphone. Values were corrected for $93 \%$ recovery of methionine as the sulphone when carried through all stages of the procedure.

(2) Hydrolysis in $6 \mathrm{~N}-\mathrm{HCl}$ followed by iodometric titration. Recovery of methionine added to cod-muscle preparations with and without glucose was 88 and $96 \%$ respectively, and values were corrected accordingly.

(3) Partial hydrolysis in $2 \mathrm{~N}-\mathrm{HCl}$ followed by assay with Strep. zymogenes as described by Ford (1962).

Cystine was determined by chromatographic separation of cysteic acid from hydrolysates of performic-oxidized material using the same conditions as previously described (Miller \& Carpenter, 1964). Lysine was determined by ion-exchange chromatography after acid hydrolysis as previously described (Carpenter, March, Milner \& Campbell, I963).

Tryptophan was determined colorimetrically after hydrolysis with $\mathrm{Ba}(\mathrm{OH})_{2}$ (Greene \& Black, r944) by a modification (Miller, 1965, unpublished procedure) of 
the method of Horn \& Jones (1945). A mean recovery of $94 \%$ was obtained for tryptophan added to samples of cod muscle and carried through all stages of the procedure, and apparent values were corrected accordingly.

Laboratory assessment of available amino acids. Available methionine, tryptophan and leucine were determined by a slight modification of the procedure of Ford (1962); the preliminary digestion of the samples was performed in $0.36 \%$ solution of papain with an enzyme activity of $\mathrm{I} \cdot 3$ units/g (cf. Rao, Sreenivas, Swaminathan, Carpenter \& Morgan, 1963). FDNB-available lysine was determined by the method of Carpenter (1960); the mean recovery of dinitrophenyl lysine added to the cod powder did not differ significantly according to the presence or absence of $10 \%$ glucose. The mean recovery value was $96 \%$ and the results were corrected for a $4 \%$ loss rather than $8 \%$ loss found with commercial fish meals.

\section{Animal experiments}

Available amino acid assays. Available methionine was determined with chicks by the growth assay procedure of Miller, Carpenter et al. (1965). Each material was tested at two levels of addition to a basal diet deficient in methionine, and results were calculated from the relationship between food conversion efficiency (FCE) and 'percentage supplementary methionine'. Available lysine was also determined with chicks by a similar growth assay procedure (Carpenter, March et al. 1963). Each material was added to the basal diet to contribute either $1 \cdot 62$ or $3.24 \%$ crude protein (CP) and the total protein level was kept constant by addition of zein. The results were again calculated from the relationship between FCE and 'percentage supplementary lysine'.

Experiments with rats. The net protein ratio (NPR) and nitrogen digestibility of control and six heated materials were determined in two experiments, each lasting Io days, with one sample repeated in each to facilitate comparisons. In the first experiment nitrogen balances were also conducted and finally the rats were killed and the carcasses analysed for nitrogen. The results of this first experiment have been previously reported (Miller, I962) and discussed with reference to the difference between nitrogen retention calculated from balance data or carcass analysis. In the present paper only the NPU values calculated from the carcass analysis results are reported; the calculation of these was modified to make allowances for metabolic and endogenous losses in proportion to food intake and body-weight respectively.

In each experiment six litters, each of three female and three male weanling albino rats, were fed for a preliminary period of 6 days on a diet containing unheated cod as the sole source of protein at a level of $7 \cdot 4 \%$. On the 6th day the litters were paired according to weight. From each pair of litters one male and one female were assigned to each of six cages so that initial weight, sex and litter origin were balanced. Six treatments were assigned at random to the six cages. This procedure was repeated with the other two pairs of litters to give three replicate units for each treatment. In each replicate block one pair of rats was killed for estimation of carcass nitrogen at the beginning of the experiment, one pair was fed on the ' $\mathrm{N}$-free' (no. I) diet previously described (Carpenter, Lea $\&$ Parr, 1963) and the remaining four pairs were 
fed on one of the test diets made by including the cod preparations to supply $10 \% \mathrm{CP}$ at the expense of $5 \%$ potato starch, $3 \%$ maize oil and the balancing amount of maize starch.

The two rat experiments were also used to determine the levels of digestible methionine in the test materials. 'Total' methionine of test materials and rat faeces was determined by the procedure of Ford (1962). The colour of the partial hydrolysates of the faecal samples was found to interfere with the turbidimetric measurement of growth. Therefore, the results were calculated from the difference in optical density measured when the bacterial cells were in suspension and again either after several days in cold storage when the cells had settled to the bottom of the tubes or after centrifugation. Assays of the test materials were conducted in an identical manner although the hydrolysates were not highly coloured. True digestibility of methionine was calculated, allowance being made for a metabolic excretion of methionine with the nitrogen-free diet in proportion to food intake.

\section{RESULTS}

The control cod-muscle powder ( $\mathrm{C}_{23}$ ) contained $2.5 \%$ moisture, $15.0 \%$ nitrogen, $5.0 \%$ ash and $\mathrm{I} \cdot 3 \%$ ether extract. Its contents of total and available amino acids, as determined by different procedures, are set out at the head of Table 2. The $\mathrm{pH}$ of a $2.5 \%(\mathrm{w} / \mathrm{v})$ aqueous suspension was 6.95 . In the preliminary experiment, ampoules representative of each preparation were not heated but retained as controls. Analysis of these controls indicated no change in amino acid availability as a result of preparation.

After heat treatment the apparent percentage moisture content had generally increased by $0.5^{-0.7}$ unit. Since this increased moisture content may have been the result of chemical reactions all the results were calculated on the basis of the dry weight and nitrogen content before heat treatment.

\section{Preliminary experiments with samples heated in glass ampoules}

Appearance and odour. Upon opening the ampoules, especially those heated at $115^{\circ}$, strong smells of ammonia and a thiol were noted. Sufficient gases were released to turn litmus paper rapidly blue and lead-acetate paper black.

The control material was almost pure white in colour, having an extinction of only 0.1 at $500 \mathrm{~nm}$ compared with the standard white magnesium carbonate. Samples heated in the absence of added glucose were creamy-yellow in colour, whereas samples heated in the presence of glucose varied from cream to deep brown according to the severity of heat treatment. The effect of moisture content during heat treatment on the darkening of the samples is shown in Fig. I. In general the more moisture the cod powder contained the more it darkened on heating, whereas with a cod-glucose mixture maximum darkening was obtained with the sample containing $14 \%$ moisture. Increasing the time of heating from $27 \mathrm{~h}$ to $729 \mathrm{~h}$ at $85^{\circ}$ had considerably less effect on the colour of the products than did increasing the temperature from $85^{\circ}$ to $115^{\circ}$ for a constant $27 \mathrm{~h}$.

Laboratory tests on cod powder heated at $14 \%$ moisture. Each material was tested microbiologically in single assays for available methionine and leucine. Duplicate 
determinations were made of FDNB-available lysine. The results were not subjected to statistical analysis, but in previous work differences of approximately го $\%$ between microbiological values and of $5 \%$ between FDNB-available lysine values were significant at the $5 \%$ level of probability (Rao et al. 1963 ).

The results with the cod powder alone are presented in histogram form in Fig. $2 a$. For each of the three treatments the proportional falls in methionine and leucine values determined microbiologically were similar, and greater than the corresponding fall in the lysine value measured with FDNB. For the mildest treatment $\left(85^{\circ}, 27\right.$ h) the lysine value was not affected whereas for the others there was a significant fall. The long-term treatment $\left(85^{\circ} ; 729 \mathrm{~h}\right)$ caused almost as much apparent damage to leucine and methionine as did the short, hot treatment $\left(\mathrm{II} 5^{\circ} ; 27 \mathrm{~h}\right)$ but considerably less damage to the lysine.

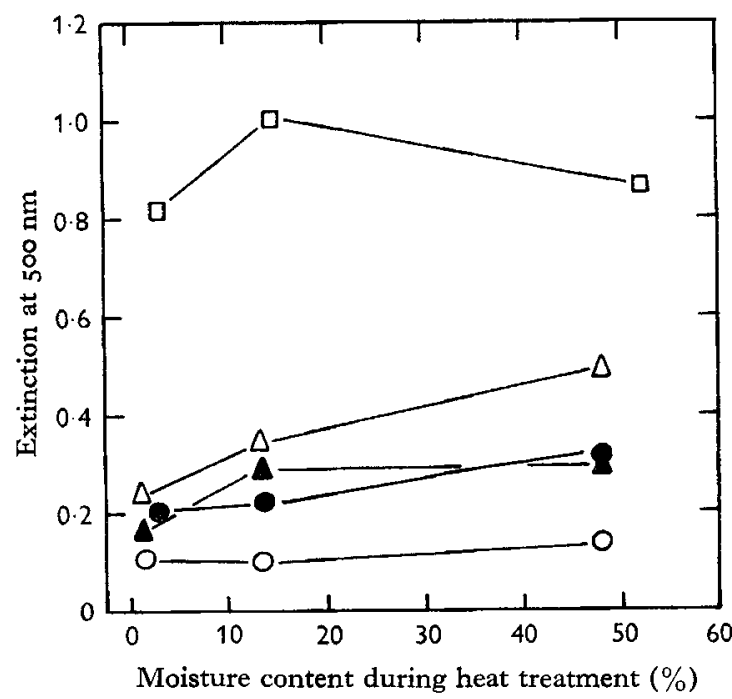

Fig. 1. Effect of heating cod muscle upon the production of colour. $\bigcirc-0$, controls; $\bullet-\bullet, 27 \mathrm{~h}$ at $85^{\circ} ; \Delta-\Delta, 27 \mathrm{~h}$ at $\operatorname{Ir} 5^{\circ} ; \Delta-\Delta, 729 \mathrm{~h}$ at $85^{\circ} ; \square-\square, 27 \mathrm{~h}$ at $85^{\circ}$ with $5 \%$ added glucose.

Contrasting results were obtained from heated cod-glucose mixtures, as seen in Fig. $2 b$. Here even the mildest treatments $\left(45\right.$ or $\left.55^{\circ} ; 9 \mathrm{~h}\right)$ caused a significant fall in the lysine value but none in that for methionine. Leucine assays were not run. With both the ' $85^{\circ} ; 27$ ' ' treatments the damage to both lysine and methionine was considerably greater with glucose present than with cod alone.

Influence of moisture on changes produced by heat. The results of heat treatment at various moisture levels are shown in Fig. 3. The driest samples (1 \% moisture, except for the samples containing glucose, which had $3 \%$ moisture) showed the least changes for all three amino acids investigated. The greatest falls in values for FDNB-available lysine occurred at $14 \%$ moisture. In contrast, microbiologically available methionine and leucine showed a greater decrease upon heating at $50 \%$ than at $14 \%$ moisture; this was particularly marked with the two treatments (no glucose) at $85^{\circ}$. 
Change in $p H$ with heating. In the absence of added glucose, increasing the temperature or the duration of heat treatment led to progressively higher $\mathrm{pH}$ values in the heated material. Cod-muscle powder heated in the presence of glucose had a lower $\mathrm{pH}$ than the other samples, and in two instances lower than that of the starting material (Fig. 4). Always the maximum $\mathrm{pH}$ was attained with material heated at $14 \%$ moisture.

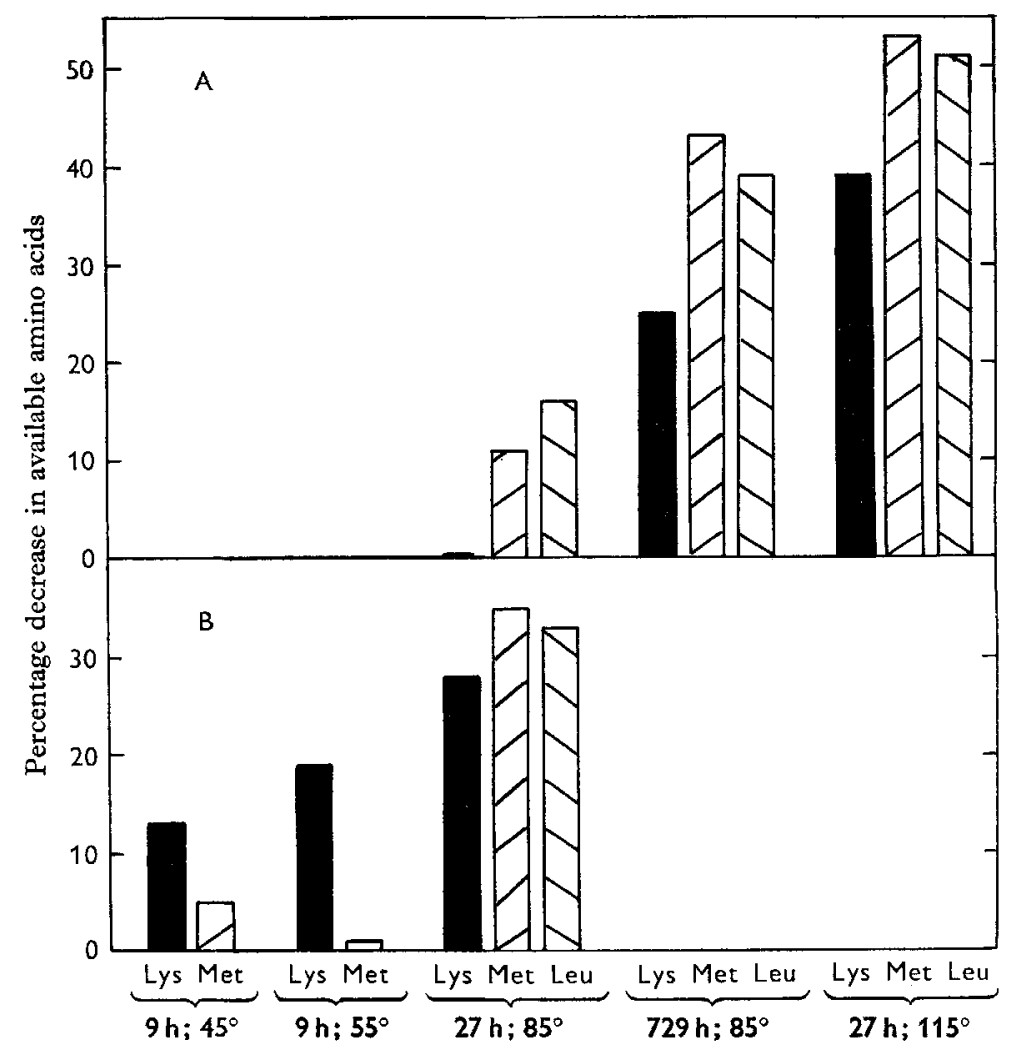

Fig. 2. Percentage decrease in available methionine and leucine (Strep. zymogenes) and in FDNB-available lysine as a result of heat treatment at $14 \%$ moisture content. A, cod muscle alone; $B$, cod muscle $+5 \%$ glucose.

\section{Main experiments with canned samples}

Chemical and microbiological results. The results are summarized in Table 2. Unless otherwise indicated, each value is the mean of two or three independent analyses. Standard errors for these values have not been calculated but are expected to be similar to values previously calculated from more extensive series of analyses (Miller \& Carpenter, 1964; Miller, Carpenter et al., 1965).

Total levels of cystine and lysine, but not of tryptophan, decreased with increasing severity of heat treatment. The three procedures used to estimate total methionine gave conflicting results. By iodometric titration and microbiological assay there was no indication of destruction of methionine in contrast to our results obtained by 


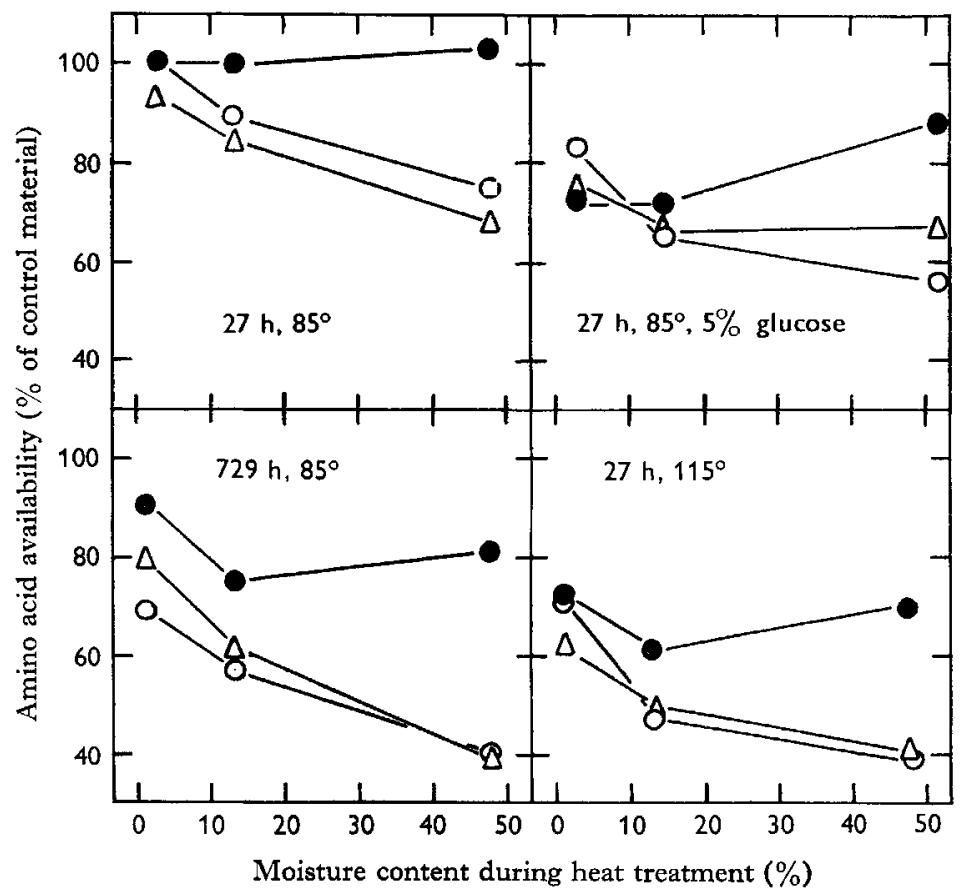

Fig. 3. Effect of various heat treatments on the availability of amino acids in cod muscle or 'cod muscle $+5 \%$ glucose' at different moisture contents. - - $\bullet$, lysine (reactivity with fluorodinitrobenzene); $-\circ$, methionine (Strep. zymogenes); $\Delta-\Delta$, leucine (Strep. zymogenes).

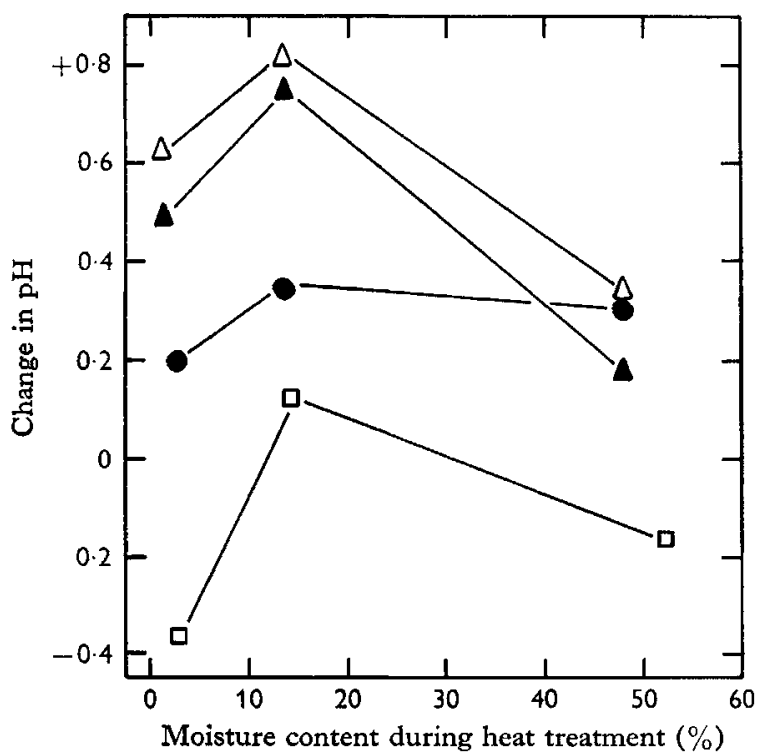

Fig. 4. Change in $\mathrm{pH}$ (from 6.95) of cod muscle as a result of heat treatment. $\bullet-\bullet, 27 \mathrm{~h}$ at $85^{\circ} ; \Delta-\Delta, 27 \mathrm{~h}$ at Ir $5^{\circ} ; \Delta-\Delta, 729 \mathrm{~h}$ at $85^{\circ} ; \square-\square, 27 \mathrm{~h}$ at $85^{\circ}$ with $5 \%$ added glucose. 
竎

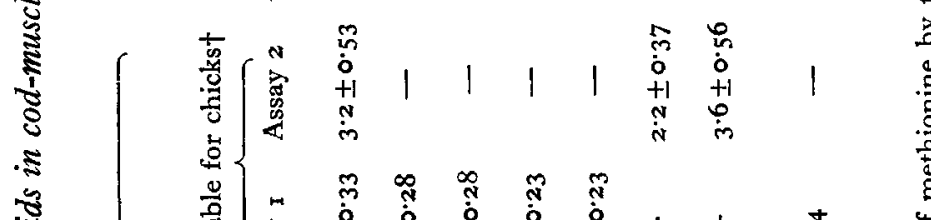

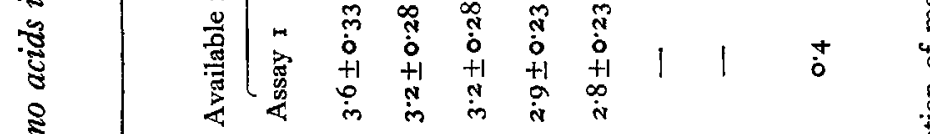

害

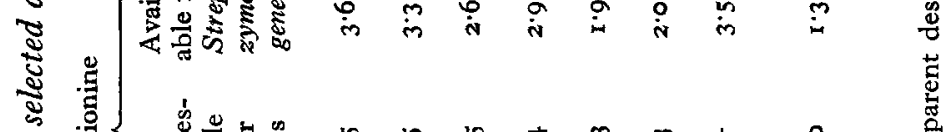

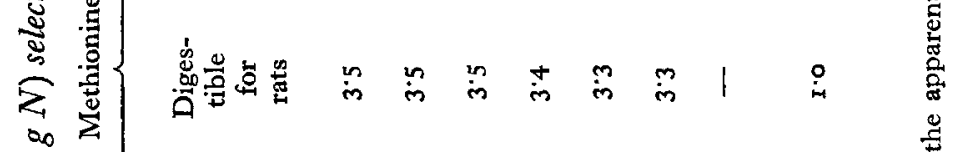

焉

㺃

传

咅

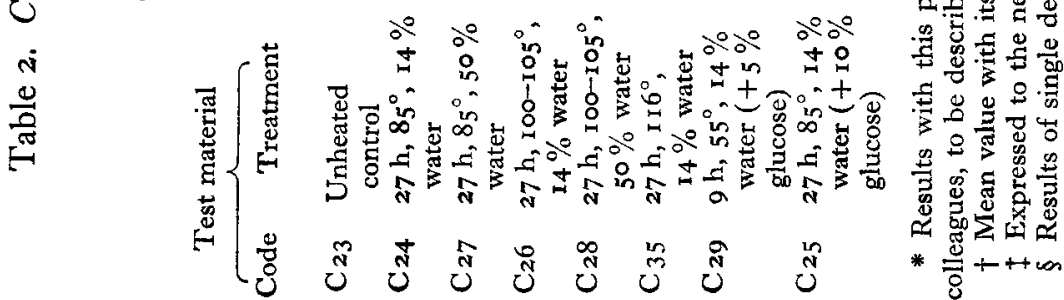


chromatographic separation of methionine sulphone. Further total amino acid analyses are set out in the following paper (Miller, Hartley \& Thomas, I965).

The 'available' amino acid values by the Strep. zymogenes and FDNB techniques were essentially the same as those obtained with ampouled material heated under similar conditions.

Chick assays for available amino acids. Two experiments were required to assay all the materials for methionine, and control material was included in each. The results of the two experiments are shown separately in Table 2 as an estimated potency for each meal and the standard error of the estimate. These standard errors cannot, however, be used for comparison of the ratios one with another, as the direct comparison of, say, $\mathrm{C}_{23}$ with $\mathrm{C}_{24}$ does not involve the use of the methionine standards and the fiducial limits of such ratios have to be calculated separately.

The reduction in available methionine upon heat treatment was similar at both moisture levels investigated; therefore the results obtained at the two moisture levels were pooled to obtain more precise estimates of the effect of temperature. Relative to a value of 100 for the control material, the methionine potencies ( \pm standard error) of material heated for $27 \mathrm{~h}$ at $85^{\circ}, 100^{\circ}-105^{\circ}$ and $\mathrm{II} 6^{\circ}$ were $87\left( \pm 5^{\circ} 9\right), 7^{\circ}\left( \pm 5^{\circ} \mathrm{I}\right)$ and $7 \circ( \pm 6.6)$ respectively. Each of these values is significantly less than the control value $(P<0.05)$ and, in addition, there is a significant linear decrease in available methionine with increase in temperature $(P<0.05)$.

Mild heating $\left(9 \mathrm{~h}\right.$ at $\left.55^{\circ}\right)$ in the presence of $5 \%$ glucose apparently had no effect upon the available methionine content, but the value calculated for the material heated in the presence of $10 \%$ glucose for $27 \mathrm{~h}$ at $85^{\circ}$ was extremely low.

Six materials were assayed for lysine available to the chick in a single experiment with the results shown in Table 2 . Heating in the absence of added glucose caused decreases in available lysine in proportions similar to decreases in available methionine. Values ( \pm standard error) relative to roo for the control material were $9 \mathrm{r}( \pm 5 \cdot 2)$, $82( \pm 5.3)$ and $5^{2}\left( \pm 5^{\circ} \circ\right)$ respectively for materials heated at $85^{\circ}, 100-105^{\circ}$ and $116^{\circ}$ for $27 \mathrm{~h}$. The mild heat treatment in the presence of $5 \%$ glucose reduced the available lysine by $18 \%$ although the available methionine was unchanged; with the material heated at $85^{\circ}$ in the presence of $10 \%$ glucose, the chicks showed virtually no response in the lysine assay.

Experiments with rats. The results of these experiments are summarized in Table 3 . It is seen that, whichever criterion of protein quality was used, heating for $27 \mathrm{~h}$ at $100^{\circ}-105^{\circ}$ caused significant damage, though heating at $85^{\circ}$ had not given products of significantly lower value than the control material. As with the chick experiments described above, heating at $85^{\circ}$ in the presence of glucose was more damaging for rats than heating at $116^{\circ}$ in its absence.

The damaging effects of heat are by no means explained by a fall in digestibility of the material. The biological value (BV) of the fraction still digested decreased even more than did digestibility when the $\operatorname{cod}\left(\mathrm{C}_{2} 6\right)$ was heated at $100^{\circ}-105^{\circ}$; and the $\mathrm{BV}$ of the material $\left(\mathrm{C}_{25}\right)$ heated with glucose decreased to about the same extent as the digestibility. The digestibility of methionine fell rather less than that of nitrogen as a whole except for sample $\mathrm{C}_{25}$, the only one in the series containing glucose. 


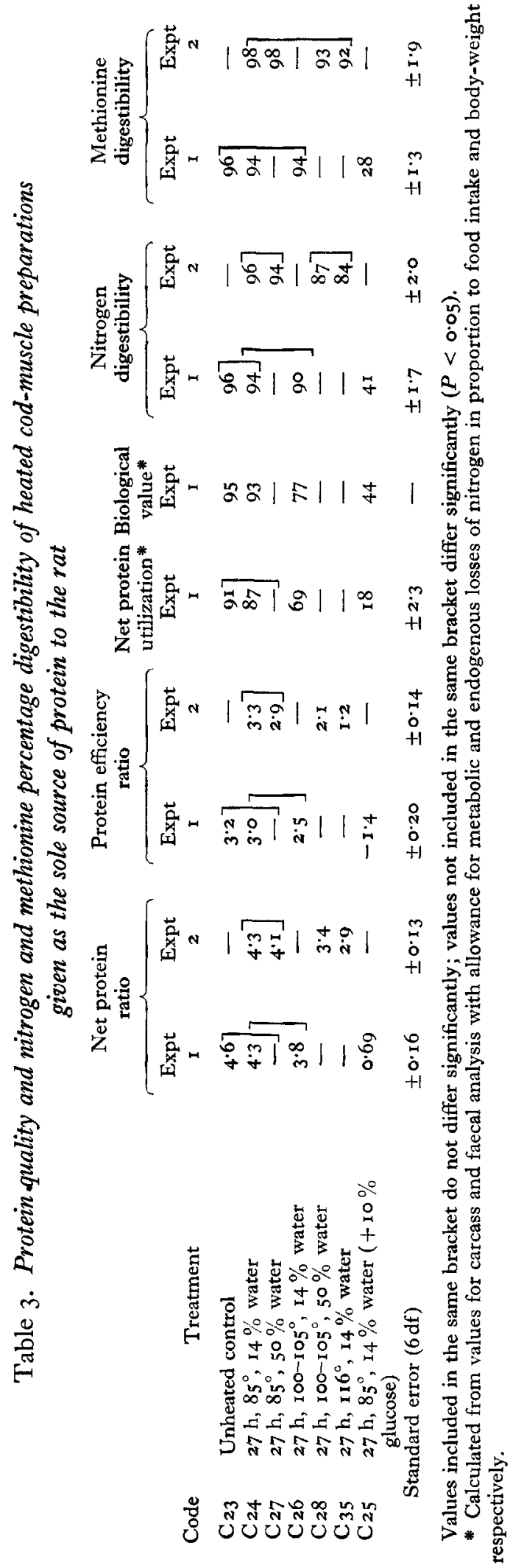




\section{DISCUSSION}

In these experiments, three distinct results of heat damage can be recognized; they have resulted from (I) severe heating (temperature $>85^{\circ}$ ) of cod fillets alone; (2) very mild heating (temperature $55^{\circ}$ or less) in the presence of glucose; and (3) heating at an intermediate temperature $\left(85^{\circ}\right)$ in the presence of glucose.

In the main experiment the most severe processing of the cod by itself was for sample $\mathrm{C}_{35}$-heated with $14 \%$ moisture at $116^{\circ}$ for $27 \mathrm{~h}$. This caused a destruction of more than half the cystine but no change in methionine content; the following paper (Miller, Hartley \& Thomas, 1965) discusses in detail the analytical problem of establishing this point. Nevertheless, the value of the protein in $\mathrm{C}_{35}$ as a source of methionine both for the chick and for the proteolytic micro-organism Strep. zymogenes was reduced to about two-thirds that of the control material, in which the methionine appeared to be fully available. Similarly, when tested as the sole protein source for rats, the NPR of $\mathrm{C}_{35}$ was reduced to about two-thirds of the control value. Many experiments have shown that in the NPR test the 'cystine + methionine' content of both good-quality and heat-damaged fish flours is the limiting factor (Miller, r956; Dreosti \& Wiechers, I960; Njaa, I96r; Carpenter, Lea \& Parr, 1963; Morrison \& Sabry, 1963).

Decrease in available sulphur amino acids also occurred at lower temperatures than I $16^{\circ}$. From chick, rat and microbiological trials it is concluded that heat conditions more severe than $85^{\circ}$ for $27 \mathrm{~h}$, achieved either by elevation of temperature or by heating for a longer time, all brought about significant loss of available sulphur amino acids.

The effect of severe heating on methionine seemed no greater than that on other amino acids which were assayed, i.e. leucine and tryptophan with Strep. zymogenes, and lysine by chick assay and reactivity with FDNB. This general decrease in availability of amino acids parallels similar findings in commercial whale-meat meals (Ford, r962). In a series of seven commercial meals we reported that the decreased availability could largely be accounted for by a low digestibility of the protein (Miller \& Carpenter, 1964). However, in the study now presented the digestibility of the nitrogen, measured with the rat, in the most severely heated material $\left(\mathrm{C}_{35}\right)$ was only $12 \%$ below that of the control, and the digestibility of methionine had decreased by only $6 \%$. Even when allowance is made for destruction of cystine, the relative NPR values indicate that a further, considerable fraction of the sulphur amino acids of $\mathrm{C}_{35}$, although not recovered in the faeces, must be in a form unavailable to the rat. Donoso et al. (1962) came to a similar conclusion from their study of sulphur and nitrogen balance of rats fed on control and heated pork protein, although interpretation of their data is complicated by there apparently being much sulphur present which was not accounted for either as cystine or methionine.

The second type of damage, brought about by heating cod and glucose mixtures at low temperatures for a short time, resulted in a decrease in total and available lysine without any change in availability of methionine, tryptophan or leucine. These results are similar to those obtained in 5-ro days' storage studies at $37^{\circ}$ on casein-glucose systems (Lea \& Hannan, r950; Rao et al. 1963). Very little colour change occurs under 
these conditions and the reactions taking place are probably the initial colourless stages of condensation between aldose sugar and free amino groups of the protein (Hodge, 1955). Destruction of lysine may occur either as a result of rearrangement of the firstformed condensation product or upon acid hydrolysis carried out as a preliminary to conventional analysis. Under these conditions lysine suffers the main damage and this has led to the observation that the nutritive value can usually be restored by lysine supplementation alone (Henry, Kon, Lea \& White, 1947-8; Mauron \& Mottu, 1958).

The third type of damage was that obtained by a more severe heat treatment of a protein-sugar mixture, though still not of the severity required to produce appreciable damage in protein by itself. In our own work $\mathrm{C}_{25}$ was prepared by heating at $85^{\circ}$ for $27 \mathrm{~h}$, but some similar effects have been obtained either by storing a casein-glucose mixture at $37^{\circ}$ for a long period at a high moisture content (Lea \& Hannan, 1950) or by autoclaving skim-milk powder at $120^{\circ}$ for an hour (Ford, 1962). Our product, $\mathrm{C}_{25}$, was dark brown with a very low availability of methionine and other amino acids, as well as of lysine. In fact, the very low growth response in the chick assays for lysine and methionine led to a suspicion that it might contain a toxic factor. However, in contrast to the effect of heating in the absence of glucose, the considerable decrease in the digestibility of the protein in $\mathrm{C}_{25}$ (observed with the rat) may have accounted for much of the loss of nutritional value.

\section{Consideration of the techniques used}

The usefulness of the chemical and microbiological methods must of course depend on how well the values they give correlate with values from direct feeding experiments. Of the results from the animal experiments, those from the chick assays for lysine have given most concern. As seen in Table 2, the value obtained for the lysine content of the control cod fillets is approximately $20 \%$ above that of the total lysine content determined chemically. An earlier result of this kind has already been reported (Carpenter, March et al. 1963) and the present result has been confirmed in a further unpublished experiment where the amino acid balance of all diets was kept constant. Finally, inter-laboratory checks of the chemical figure (Miller, Hartley \& Thomas, 1965) have failed to show large error in the original value. Since a figure of ' $120 \%$ availability' is meaningless, it seems that the values from these lysine assays can only be regarded as indicative of the relative values of protein supplements. Recently, Smith \& Scott $\left(1_{96} 6_{5}\right)$ have also reported apparent availabilities greater than $100 \%$ for a number of amino acids in assays of two fish meals with chicks. The various problems connected with such assays have been reviewed by Harper \& de Muelenaere ( 1963$)$.

The results of the chick assays for methionine have not shown inconsistencies with other data. However, it would be imprudent to transfer conclusions from the rat to the chick or vice versa. In particular, the digestibility measurements with the rats were made in conventional metabolism cages that allow coprophagy, so that very small falls in digestibility values for methionine may just possibly be due in part to considerable re-cycling of intestinal contents with bacterial conversion of some indigestible methionine into forms not measured by our procedures.

The Strep. zymogenes assay for available methionine has already been shown to give 
a close correlation with chick assay values for a range of materials that included all but those containing added glucose (i.e. $\mathrm{C}_{25}$ and $\mathrm{C}_{29}$ ) of the present series (Miller, Carpenter et al. 1965 ). However, there is one point on which the micro-organism has failed to predict results with the chick. Microbiological assays for available methionine have repeatedly given considerably lower figures whenever cod has been heated at $50 \%$ moisture as compared with $14 \%$ moisture content, i.e. at $85^{\circ}$ and $115^{\circ}$ in the ampouled series (Fig. 3) and at $85^{\circ}$ and $100^{\circ}-105^{\circ}$ in the canned series (Table 2). Chick assay I failed to show such differences, although effects of the same magnitude should have been detectable.

Strep. zymogenes assays for tryptophan and leucine have shown the same pattern as those for methionine with cod fillets heated at different moisture contents. With de-fatted herring press-cake heated at $130^{\circ}$ no such effect of high moisture content was observed, and minimum methionine values were obtained in samples at about $10 \%$ moisture content (Carpenter et al. 1962).

Heating cod fillets at $50 \%$ as opposed to $14 \%$ moisture content, as already observed with dried pork (Donoso et al. 1962), led to considerably greater darkening of the material. Also, in our rat experiments there was an indication that the samples heated at the higher moisture content were slightly inferior. Miller (1956) found that heating acetone-extracted cod muscle at increasing relative humidity led to progressive lowering of the NPU of the products, although differences were not significant after heating at $69 \%$ and $97 \%$ r.h. respectively.

We have not relied on the 'faecal analysis method' (cf. review by Harper \& de Muelenaere, 1963) for estimating the availability for rats of methionine in our samples; however, these are what we have called 'digestible methionine' and tabulated in Table 2. As will be seen, heat treatment (apart from $\mathrm{C}_{25}$ ) has had very little effect on the value, so that the results are in contrast with those obtained by all other procedures.

In general, as shown in the previous paper of the series (Miller, Carpenter et al. 1965), Strep. zymogenes-available methionine and FDNB-available lysine appear to be comparable indications of heat damage to animal proteins. However, as is brought out in Fig. 3, this is not so for cod protein heated at high moisture content, and further study is required of the heat damage under these conditions.

\section{Explanations for the unavailability of methionine}

Since the evidence from the Strep. zymogenes assay for leucine is that this amino acid, with its paraffin (and presumably inert) side-chain, becomes unavailable to roughly the same extent as methionine, lysine or tryptophan as a result of heat treatment of cod fillets, there seems no reason to postulate any chemical mechanism with a specific effect on methionine.

The general explanation, first suggested by Mecham \& Olcott (1947) for these and other changes observed to result from the heating of relatively pure proteins, in contrast to those from mild treatment of protein-sugar mixtures, has been that crosslinkages are formed from one amino acid unit to another, both within and between molecules. These have been postulated as condensations between free amino or 
hydroxyl groups on the one hand and carboxyl groups on the other. The changes in $\mathrm{pH}$ of heated materials, as shown in Fig. 3, are consistent with this, i.e. they show a rise in $\mathrm{pH}$ as might be expected with the formation of ester linkages whereas, in the presence of glucose, where amino linkages are thought to predominate, the $\mathrm{pH}$ did not show the same rise.

It is understandable that such cross-linkages should hinder enzymic attack and the release of even those amino acids not directly involved. However, it is less clear why the final digestibility of proteins containing such cross-linkages should apparently be so little affected or why a general delay in proteolysis and absorption should be so growth-depressant. Melnick \& Oser (1949) have suggested that with heat-damaged protein foods some amino acids may be released later than others so that mutual supplementation becomes ineffective. The design of our own experiments was such that they give no evidence one way or the other for such a differential release.

\section{Explanation of damage in commercial materials}

The first paper in this series reported the poor digestibility for rats of both the nitrogen and sulphur in some commercial samples of animal protein concentrates (Miller \& Carpenter, 1964) and the second paper reported the low availability-in three instances less than $50 \%$ - of the methionine in the same samples for chicks (Miller, Carpenter et al. 1965). One aim of the study now presented was to reproduce such damage by the controlled heat treatment of good-quality starting material in the laboratory.

The most drastic heat treatment, $27 \mathrm{~h}$ at $1 \mathrm{I} 6^{\circ}$, applied to the cod fillets alone at $14 \%$ moisture content, reduced the available methionine to $69 \%$ of its original value in the chick assay, and the FDNB-available lysine value was reduced in almost the same proportion. It is not suggested though that commercial samples of low quality must have been exposed to such severe conditions during drying.

From the kind of tests used in the present investigation it has seemed that ordinary commercial drying causes very little damage to the protein in fish meals (Carpenter et al. 1962; Carpenter, Lea \& Parr, 1963). From the known history of samples shown to be of low quality, it appears more likely that the damage was the result of overheating during storage (Laksesvela, 1958; Bunyan \& Woodham, 1964) which in turn was caused by autoxidation of residual lipids (cf. review by van den Brock, 1959).

There is some evidence that oxidation of the lipids has a double action; in addition to being exothermic the reactions provide breakdown products with free carbonyl groups that may react with proteins at lower temperatures than those required to damage protein per se. Thus, holding fresh herring meal in $\mathrm{N}_{2}$ at $85^{\circ}$ for $30 \mathrm{~h}$ did not result in a fall in FDNB-available lysine, but a $10 \%$ decrease was obtained either with oxidized meal held in $\mathrm{N}_{2}$ or with fresh meal held in air (Lea et al. 1960).

With herring meals it seems certain that some heat is necessary for the oxidized fat to cause serious damage to the protein with which it is in contact. On several occasions, I2 months' storage of herring meals at 20 or $25^{\circ}$, during which time the $10 \%$ or so of lipids present have oxidized so that their initial iodine value has fallen from approximately $\mathrm{I}_{35}$ to 85 , has resulted in only an 8-9\% loss of FDNB-available 
lysine (Lea et al. 1958, 1960) and neither feeding trials nor Strep. zymogenes values for available methionine showed a greater fall (Carpenter, Lea \& Parr, 1963). However, with menhaden meal, which has residual oil that is even more unsaturated, it appears that long periods of storage even at room temperature may lead to considerably greater falls in nutritive value (Ousterhout \& Snyder, I962).

It still remains to study the effects of heating protein in the presence of oxidizing fat. Possibly the damage will prove to be of the same type as that observed when protein is heated at moderate temperatures with glucose as a source of carbonyl groups.

\section{SUMMARY}

I. Freeze-dried cod muscle was subjected to sixteen different conditions of heat treatment, with moisture content ranging from I to $50 \%$, temperature from 45 to I $16^{\circ}$ and time from 9 to $729 \mathrm{~h}$; in a few of the treatments the dried muscle was first mixed with 5 or $10 \%$ glucose.

2. All the samples were assayed for 'available' methionine and leucine with Streptococcus zymogenes by a slight modification of the Ford (1962) procedure and for fluorodinitrobenzene-available lysine as described by Carpenter (1960).

3. Larger batches prepared by selected heat treatments were subjected to further amino acid analysis and assayed for protein quality in net protein utilization (NPU) or net protein ratio (NPR) tests with rats, and for available methionine and lysine with chicks.

4. The treatments without added glucose destroyed up to two-thirds of the cystine in the cod muscle. There was no destruction of methionine, but up to one-third became unavailable for chicks. The NPR values for rats also fell by up to one-third.

5. Digestibility of the protein as determined with the rat fell with heat treatment, but not sufficiently to explain the fall in NPU so that some of the 'digested methionine' from heated materials may have been of reduced value for growth promotion, i.e. apparently unavailable.

6. As judged by the feeding tests with chicks, the proportions of lysine and methionine made unavailable by heat treatments were similar. Methionine was no more affected than leucine in the Strep. zymogenes assays of the full series of treatments.

7. In general, the Strep. zymogenes assays proved a useful indicator of the extent to which heat damage resulted in methionine becoming unavailable for chicks. However, there was an indication (in need of further investigation) that Strep. zymogenes can give unduly low available methionine values for cod muscle heated at $50 \%$ moisture content and so fail to model the chick or rat.

8. Mild heat treatment in the presence of glucose caused damage to lysine but not to methionine. However, the presence of $10 \%$ glucose in material heated for $27 \mathrm{~h}$ at $85^{\circ}$ greatly reduced the values in all the assays for amino acids and the digestibility of the protein for rats.

We are grateful for grants for the support of this work from the Agricultural Research Council and from the United States Department of Agriculture (grant FG-UK-127). The freeze-dried cod fillets were kindly given to us by the Unilever Ltd 
Experimental Factory, Aberdeen. We are indebted to Mr A. W. Boyne and Dr R. C. Campbell who carried out the statistical analyses of the chick assays for methionine and lysine respectively.

\section{REFERENCES}

Association of Official Agricultural Chemists (1960). Official Methods of Analysis, 9th ed., para. 2.034. Washington, DC: Association of Official Agricultural Chemists.

Bunyan, J. \& Woodham, A. A. (1964). Br. Y. Nutr. 18, 537.

Carpenter, K. J. (1960). Biochem. F. 77, 604.

Carpenter, K. J., Ellinger, G. M., Munro, M. I. \& Rolfe, E. J. (1957). Br. F. Nutr. rr, I6z.

Carpenter, K. J., Lea, C. H. \& Parr, L. J. (1963). Br. F. Nutr. I7, I5r.

Carpenter, K. J., March, B. E., Milner, C. K. \& Campbell, R. C. (r963). Br. F. Nutr. 17, 309.

Carpenter, K. J., Morgan, C. B., Lea, C. H. \& Parr, L. J. (I962). Br. F. Nutr. 16, 45 I.

Donoso, G., Lewis, O. A. M., Miller, D. S. \& Payne, P. R. (1962). F. Sci. Fd Agric. 13, 192.

Dreosti, G. M. \& Wiechers, S. G. (1960). Rep. Fishg Ind. Res. Inst., Cape Tn, no. I4, p. 3 I.

Ford, J. E. (1962). Br. F. Nutr. 16, 409 .

Ford, J. E. (1964). Br. F. Nutr. 18, 449.

Greene, R. D. \& Black, A. (×944). F. biol. Chem. 155, 1.

Harper, A. E. \& de Muelenaere, H. J. H. (1963). Proc. int. Congr. Biochem. v. Moscow, 8, 82.

Henry, K. M., Kon, S. K., Lea, C. H. \& White, J. C. D. (1947-8). F. Dairy Res. 15, 292.

Hodge, J. E. (1955), Adv. Carbohyd. Chem. ro, r69.

Horn, M. J. \& Jones, D. B. (1945). F. biol. Chem. 157, I53.

Laksesvela, B. (1958). F. agric. Sci., Camb., 51, 164.

Lea, C. H. \& Hannan, R. S. (1950). Biochim. biophys. Acta, 5, 433.

Lea, C. H., Parr, L. J. \& Carpenter, K. J. (1958). Br. F. Nutr. 12, 297.

Lea, C. H., Parr, L. J. \& Carpenter, K. J. (1960). Br. J. Nutr. 14, 9 1.

$\mathrm{Ma}$, T. S. \& Zuazaga, G. (I942). Ind. Engng Chem. analyt. Edn, 14, 280.

Mauron, J. \& Mottu, F. (1958). Archs Biochem. Biophys. 77, 312.

Mecham, D. K. \& Olcott, M. S. (1947). Ind. Engng Chem. ind. Edn, 39, 1023.

Melnick, D. \& Oser, B. L. (1949). Fd Technol., Lond., 3, 57.

Miller, D. S. (1956). F. Sci. Fd Agric. 7, 337.

Miller, E. L. (1962). The evaluation of foods as sources of the sulphur-containing amino acids. PhD Thesis, University of Cambridge.

Miller, E. L. \& Carpenter, K. J. (1964). F. Sci. Fd Agric. 15, 810.

Miller, E. L., Carpenter, K. J., Morgan, C. B. \& Boyne, A. W. (1965). Br. F. Nutr. 19, 249.

Miller, E. L., Hartley, A. W. \& Thomas, D. C. (1965). Br. F. Nutr. 19, 565.

Morrison, A. B. \& Sabry, Z. I. (r963). Can. F. Biochem. Physiol. 41, 649.

Njaa, L. R. (I96r). F. Sci. Fd Agric. 12, 757 .

Ousterhout, L. E., Grau, C. R. \& Lundholm, B. D. (1959). F. Nutr. 69, 65.

Ousterhout, L. E. \& Snyder, D. G. (1962). Poult. Sci. 4r, I753.

Rao, M. N., Sreenivas, H., Swaminathan, M., Carpenter, K. J. \& Morgan, C. B. (1963). F. Sci. Fd Agric. I4, 544.

Rice, E. E. \& Beuk, J. F. (1953). Adv. Fd Res. 4, 233.

Smith, R. E. \& Scott, H. M. (1965). Poult. Sci. 44, 401 .

van den Brock, C. H. J. (1959). Fd Mf. 34, 349.

Note added in proof. H. E. Power (1964) (F. Fish. Res. Bd Can. 21, 1489) has reported that cod fillets contain $14.2 \mathrm{~g}$ lysine $/ 16 \mathrm{~g} \mathrm{~N}$ and I. C. Munro \& A. B. Morrison $\left(\mathrm{I}^{6} 6_{5}\right)$ ( $\mathcal{F}$. Fish. Res. Bd Can. 22, 13 ) have reported a value of $12 \cdot 3 \mathrm{~g} / 16 \mathrm{~g} \mathrm{~N}$, in each instance from microbiological assay with Leuconostoc mesenteroides. High values with this assay can result from the presence of hydroxylysine (HOL) in test materials (cf. K. J. Carpenter, A. W. Hartley \& L. D. Ward, I964) (Proc. Nutr. Soc. 23, $\mathrm{xl}$ ). However, cod fillets contain little HOL. We obtained with Leuc. mesenteroides values of 9.5 and $9.7 \mathrm{~g}$ lysine $/ \mathrm{I} 6 \mathrm{~g} \mathrm{~N}$ respectively using media with and without HOL, i.e. results similar to the $9.3 \mathrm{~g} / \mathrm{r} 6 \mathrm{~g} \mathrm{~N}$ found by ion-exchange chromatography. 